\title{
The Relationship Between Knowledge Levels and Attitudes About Waste Management Against Garbage Disposal Behavior in RW 06 Oro-Oro Dowo Malang City in 2019
}

\author{
Ema Novita Deniati ${ }^{1, *}$ Annisaa Annisaa ${ }^{2}$ \\ ${ }^{1,2}$ Department of Public Health, Faculty of Sport Science, Universitas Negeri Malang, Malang, East Java, Indonesia \\ *Corresponding author. Email: ema.deniati@fik.um.ac.id
}

\begin{abstract}
Knowledge and attitudes have a close relationship in bringing up a behavior, especially environmental health behavior. The environment is still a major problem for environmental health, especially related to waste management. The community in RW 06 Oro-Oro Dowo Village, Klojen District, Malang City also feels the problem of waste. The waste management behavior carried out includes burning garbage, making a dump or a hole in the ground as a place for garbage disposal and then burying it, and throwing garbage on the side of the river. During the rainy season in RW 06 , there must be flooding of approximately $1 \mathrm{M}$ high, especially the houses that are close to the river. This research is a quantitative-research using questionnaires and observations and is a type of cross-sectional research. From the research that has been done, it is found that $57 \%$ of the people have good knowledge about waste management, $57 \%$ are supportive of waste management, and about $43 \%$ of the people have good behavior about waste management. Based on the results of the binary logistic regression test, a significance value of 0.467 was obtained. Because the significance value is $0.467>0.05$, it can be concluded that $\mathrm{H} 0$ is accepted and $\mathrm{Ha}$ is rejected. This means that there is no relationship between knowledge and attitudes about waste and the behavior of disposing of waste in the community of RW 06 Orooro Dowo Village, Malang City.
\end{abstract}

Keywords: knowledge, attitude, behavior, management, waste

\section{INTRODUCTION}

Health as an indicator of the level of community welfare related to the environment [1]. Environmental health, especially the environment, plays a role in preventive efforts to realize a healthy quality of the environment, both physical, chemical, biological, and social, which allows every individual or society to achieve the highest degree of health [2]. At present, the environment is still a problem that is paid much attention to by academics, politicians, and the public because of the deteriorating condition of the earth. To prevent environmental problems from getting worse, efforts are made to improve environmental sanitation by implementing good sanitation in the environment around the place of residence.

House sanitation conditions are influenced by various factors such as socio-economic factors, education, knowledge, attitudes and behavior of each family member. House conditions that do not meet health requirements can cause various kinds of diseases or health problems such as Tuberculosis (TBC), ARI, skin diseases, injuries, dengue fever, and so on. According to research by Nurnahdiaty, et al (2014) shows that family health rests on the mother who plays the role of decision maker, care for family members, maintenance of the living environment, utilization of family health facilities and waste management [3].

Bad habits of disposing of waste include littering and littering, throwing garbage in rivers, mixing dry waste with wet and organic with inorganic. These wrong habits can lead to silting of rivers, contamination of water sources, trigger flooding during the rainy season, and can trigger a high risk of disease. In addition, the presence of waste that is not managed properly can produce leachate and methane gas as a form of greenhouse gases in the atmosphere. Burning waste also causes air pollution 
which adds to global warming and affects climate change [4].

The community in RW 06 Oro-Oro Dowo Village, Klojen District, Malang City also feels the problem of waste. RW 06 consists of 4 RT starting from the alley next to Indomart (Gang III) to the alley next to SMA Muhammadiyah Malang (Gang VIII). The number of families in RW 06 is approximately 200 families [5]. In RW 06 waste management is carried out by the residents themselves, especially youth groups. The waste management behavior carried out includes burning garbage, making a dump or a hole in the ground as a place for garbage disposal and then burying it, and throwing garbage on the side of the river. During the rainy season in RW 06, there will be flooding of approximately $1 \mathrm{~m}$ high, especially the houses that are close to the river. For health problems that arise due to floods such as diarrhea, dengue fever or skin diseases, there is no such thing until now. This happens because the residents living in RW 06 are already immune to health problems when it rains. The health problems that residents of RW 06 often complain about are mostly mild illnesses such as: dizziness, flu and cough.

Based on the problems that occurred in RW 06 OroOro Dowo, Klojen District, Malang City, it is important to know the relationship between the level of knowledge and public attitudes about waste management on waste disposal behavior. Garbage is residual material that is not used, generally comes from activities carried out by humans, not including biological activities [6]. Waste management as a systematic, comprehensive, and sustainable activity to reduce and handle waste includes five aspects, namely institutional aspects, financing, regulation, community participation, and operational techniques [7].

Knowledge is the result of knowing someone from his own experience or from the experience of others to form an action. Knowledge is influenced by several factors, including experience, level of education, beliefs, sources of information, socio-culture, and age. Attitude as a reaction or response of someone who is still closed to a stimulus consists of three components, namely perceptual or cognitive related to knowledge, views and beliefs; emotional or affective related to feelings of pleasure and displeasure with waste management; and behavior or actions related to the intensity of waste management. Knowledge and attitude is a relationship that has a strong influence. This is supported by the statement that knowledge is a very important domain in shaping one's actions. Action will continue if it is based on positive knowledge.

\section{METHOD}

The population in this study is divided into the target population and the accessible population. The target population is all residents in Oro-Oro Dowo Village and the accessible population is residents in RW 06 Oro-Oro Dowo Village. While the sample used in this study was taken using a non-probability sampling technique with quota sampling. The sample used in this study amounted to 30 people, according to the minimum sample required in a study [8].

This research is a quantitative study using a questionnaire that contains questions about the knowledge of residents about waste, residents' attitudes towards waste management, and residents' behavior regarding waste processing as a research instrument. This study used a cross sectional approach and data analysis was carried out by using the chi square test and binary logistic regression. This study aims to determine the relationship of the independent variable, namely public knowledge with the dependent variable, namely attitudes and behavior in processing waste in the community in RW 06 Oro-Oro Dowo Village, Malang City.

\section{RESULTS AND DISCUSSION}

\subsection{Overview of Oro-Oro Dowo Society}

Oro-oro Dowo is a sub-district in Klojen, Malang City, which consists of $10 \mathrm{RW}$ and $97 \mathrm{RT}$ with an area of $\pm 1,375 \mathrm{~km} 2$. RW 06 in Oro-oro Dowo Village consists of 4 RTs starting from alley III next to Indomaret to alley VIII next to Muhammadiyah Malang Senior High School. RW 06 consists of 200 families [9].

Waste management is carried out independently by youth organizations and residents in RW 06 Oro-oro Dowo. Meanwhile, the janitor from the Environment Service only cleaned the garbage around Oro-oro Dowo street. In a month, residents of RW 06 are charged a fee of 10,000 per household to pay 2 people who carry garbage from RW 06. Even though they are subject to fees, there are still RTs that do not require contributions for their residents.

Health activities that are routinely carried out in RW 06 are Integrated Healthcare Center for the elderly and toddlers which are held every first Thursday at the RW 06 hall. Based on data from Integrated Healthcare Center, there are several health complaints that are often experienced by residents of RW 06 , namely dizziness, flu, and cough. When the rainy season arrives, RW 06 is always flooded with approximately 1 meter high, especially the house which is located near the river. For health problems due to flooding such as diarrhea, dengue fever, or skin diseases, there are still no available in RW 06.

\subsection{Characteristics of Respondents}

Characteristics of respondents in RW 6 Oro-oro Dowo Village, Malang City, were distinguished by 
gender, age, last education, occupation, and RT (Table $1)$.

Table 1. Characteristics of respondents

\begin{tabular}{|c|c|c|}
\hline Characteristics & n & $\begin{array}{c}\text { Percent } \\
(\boldsymbol{\%})\end{array}$ \\
\hline Gender & & \\
\hline Woman & 29 & 97 \\
\hline Man & 1 & 3 \\
\hline Age & 1 & 3 \\
\hline$<21$ years & 6 & 20 \\
\hline 21-30 years & 4 & 13 \\
\hline 31-40 years & 5 & 17 \\
\hline 41-50 years & 8 & 27 \\
\hline $51-60$ years & 6 & 20 \\
\hline 61-70 years & & \\
\hline Last Education & 7 & 27 \\
\hline Elementary School & 13 & 23 \\
\hline Junior High School & 1 & 43 \\
\hline Senior High School & 1 & 3 \\
\hline University & & \\
\hline No school & 20 & 67 \\
\hline Profession & 3 & 10 \\
\hline Housewife & 7 & 23 \\
\hline Private sector & & \\
\hline Entrepreneur & 4 & 13 \\
\hline Residence & 7 & 23 \\
\hline RT 1 & 8 & 17 \\
\hline RT 2 & 2 & 40 \\
\hline RT 3 & & \\
\hline RT 4 & & 3 \\
\hline RT 6 & & \\
\hline & & \\
\hline
\end{tabular}

Based on gender, $97 \%$ of respondents were female and $3 \%$ of respondents were male. Based on age, there are $3 \%$ respondents aged $<21$ years, $20 \%$ respondents aged $21-30$ years, $13 \%$ respondents aged $31-40$ years, $17 \%$ respondents aged 41-50 years, $27 \%$ respondents aged 51-60 years, and $20 \%$ of respondents aged 61-70 years. Based on their latest education, about $27 \%$ of respondents had education up to elementary school, about $23 \%$ of respondents had education up to junior high school level, about $43 \%$ of respondents had education up to high school, about $3 \%$ of respondents had education up to college, and about $3 \%$ of respondents did not go to school. Based on the work, it is dominated by housewives around $67 \%$, then entrepreneurs as much as $23 \%$ and private sector as much as $10 \%$. Based on place of residence, there are $13 \%$ of respondents in RT $1,23 \%$ of respondents in RT 2, $17 \%$ of respondents in RT 3, $40 \%$ of respondents in RT 4 and $7 \%$ of respondents in RT 6.

\subsection{Categories of Respondent's Knowledge and Attitudes}

Variable knowledge of respondents is divided into three categories, namely good, sufficient and less. Respondents are categorized as having good knowledge if the answer score is $70 \%$, categorized as sufficient if the respondent's answer score is $50-69 \%$ and categorized as lacking if the answer score is $<50 \%$. Based on the results of respondents' answers, it can be concluded with the distribution table as follows (Table 2).

Table 2. Distribution knowledge variable

\begin{tabular}{|l|c|c|}
\hline \multicolumn{1}{|c|}{ Variable } & n & \% \\
\hline Knowledge & & \\
\hline Good & 17 & 57 \\
\hline Enough & 12 & 40 \\
\hline No Enough & 1 & 3 \\
\hline
\end{tabular}

Based on table 2, it can be stated that a number of 17 respondents with good knowledge obtained a percentage of $57 \%$, while a number of 12 respondents with sufficient knowledge obtained a percentage of $40 \%$, and a number of 1 respondent with less knowledge obtained a percentage of $3 \%$.

The respondent's attitude variable is divided into two categories, namely supporting and not supporting. Respondents are categorized as having a supportive attitude if the answer score is $70 \%$, while the respondent's attitude is categorized as not supportive if the respondent's answer score is $<70 \%$. Based on the results of respondents' answers, it can be concluded with the distribution table as follows (Table 3 ).

Table 3. Distribution attitude variable

\begin{tabular}{|c|c|c|}
\hline \multicolumn{1}{|c|}{ Variable } & n & \% \\
\hline Attitude & & \\
\hline Support & 17 & 57 \\
\hline Does not Support & 13 & 43 \\
\hline
\end{tabular}

Based on table 3, it can be stated that a number of 17 respondents with a supportive attitude obtained a percentage of $57 \%$, while a number of 13 respondents with a non-supportive attitude obtained a percentage of $43 \%$.

The behavioral variables of the respondents were divided into two categories, namely good and bad. Respondents are categorized as having good behavior if the answer score is $70 \%$, while the respondent's behavior is categorized as bad if the respondent's answer score is $<70 \%$. Based on the results of respondents' answers, it can be concluded with the distribution table as follows (Table 4).

Table 4. Distribution behavior variable

\begin{tabular}{|l|l|l|}
\hline \multicolumn{1}{|c|}{ Variable } & n & \% \\
\hline Behavior & & \\
\hline Good & 13 & 43 \\
\hline $\mathrm{Bad}$ & 17 & 57 \\
\hline
\end{tabular}

Based on table 4, it can be stated that a number of 13 respondents with good behavior obtained a percentage of $43 \%$, while a number of 17 respondents with bad behavior obtained a percentage of $57 \%$. 


\subsection{The Relationship of Knowledge about Garbage with Disposal Waste Behavior}

The following is a distribution table of the relationship between knowledge about waste and the behavior of disposing of waste in RW 06 Oro-oro Dowo Malang City (Table 5).

Table 5. Relationship between knowledge about waste and disposal waste behavior

\begin{tabular}{|l|c|c|c|c|}
\hline \multirow{2}{*}{ Knowledge } & \multicolumn{4}{|c|}{ Behavior } \\
\cline { 2 - 5 } & \multicolumn{2}{|c|}{ Bad } & \multicolumn{2}{c|}{ Good } \\
\cline { 2 - 5 } & n & \% & n & \% \\
\hline Good & 10 & 58.8 & 7 & 41.2 \\
\hline Enough & 7 & 58.3 & 5 & 41.7 \\
\hline No enough & 0 & 0 & 1 & 100 \\
\hline Total & 17 & 56.7 & 13 & 43.3 \\
\hline
\end{tabular}

It can be seen that most of the respondents $(56.7 \%)$ have bad behavior. As many as $58.8 \%$ of respondents who behave badly, have good knowledge and there are no respondents with less knowledge who behave badly. These results were then analyzed using the Chi Square test and the Asymp value was obtained. Sig. (2-sided) in Pearson's test is 0.508. Because the value of Asymp. Sig. (2-sided) $0.508>$ value $(0.05)$, it can be concluded that $\mathrm{H} 0$ is accepted and Ha is rejected, which means that there is no relationship between knowledge about waste and waste disposal behavior in RW 06 Oro-oro Dowo Village, Malang City.

\subsection{The Relationship between Attitude and Disposal Waste Behavior}

The following is a distribution table of the relationship between the attitude of disposing of waste and the behavior of disposing of waste in RW 06 Oro-oro Dowo, Malang City (Table 6). It can be seen that most of the respondents $(56.7 \%)$ have bad behavior. As many as
$52.9 \%$ of respondents or 9 respondents who behave badly, have an attitude of supporting waste management. Meanwhile, there are $61.5 \%$ of respondents or 8 respondents with attitudes that do not support waste management and have bad behavior. These results were then analyzed using the Chi Square test and the Asymp value was obtained. Sig. (2-sided) in Pearson's test is 0.638. Because the value of Asymp. Sig. (2-sided) 0.638 $>$ value (0.05), it can be concluded that $\mathrm{HO}$ is accepted and $\mathrm{Ha}$ is rejected, which means that there is no relationship between the attitude of disposing of waste and the behavior of disposing of waste in RW 06 Oro-oro Dowo Village, Malang City.

Table 6. Relationship between attitude and disposal waste behavior

\begin{tabular}{|l|c|c|c|c|}
\hline \multirow{3}{*}{ Attitude } & \multicolumn{4}{|c|}{ Behavior } \\
\cline { 2 - 5 } & \multicolumn{2}{|c|}{ Bad } & \multicolumn{2}{c|}{ Good } \\
\cline { 2 - 5 } & $\mathbf{n}$ & \% & n & \% \\
\hline Support & 9 & 52.9 & 8 & 47.1 \\
\hline No support & 8 & 61.5 & 5 & 38.5 \\
\hline Total & 17 & 56.7 & 13 & 43.3 \\
\hline
\end{tabular}

\subsection{The Relationship between Knowledge and Attitude with Disposal Waste Behavior}

The following is a distribution table of the relationship between knowledge and attitudes about waste and the behavior of disposing of waste in RW 06 Oro-oro Dowo Malang City (Table 7).

Based on the results of the binary logistic regression test, a significance value of 0.467 was obtained. Because the significance value is $0.467>0.05$, it can be concluded that $\mathrm{HO}$ is accepted and $\mathrm{Ha}$ is rejected, thus it can be interpreted that "There is no relationship between knowledge and attitudes about waste and waste disposal behavior in the community of RW 06 Oro-oro Dowo Village, Malang City".

Table 7. Relationship between knowledge and attitude with disposal waste behavior

\begin{tabular}{|l|l|c|c|c|c|c|c|c|c|}
\hline \multicolumn{2}{|c|}{} & \multirow{2}{*}{ B } & \multirow{2}{*}{ SE } & \multirow{2}{*}{ Wald } & \multirow{2}{*}{ df } & \multirow{2}{*}{ Sig. } & \multirow{2}{*}{$\operatorname{Exp}(\mathbf{B})$} & \multicolumn{2}{|c|}{ CI 95\% } \\
\hline Step $1^{\mathrm{a}}$ & Pengetahuan & .446 & .666 & .449 & 1 & .503 & 1.563 & .423 & 5.768 \\
\hline & Sikap & -.416 & .762 & .297 & 1 & .568 & .660 & .148 & 2.940 \\
\hline & Constant & -.333 & 1.412 & .056 & 1 & .813 & .717 & & \\
\hline Step 2 $^{\mathrm{a}}$ & Pengetahuan & .401 & .659 & .371 & 1 & .543 & 1.494 & .410 & 5.439 \\
\hline & Constant & -.860 & 1.043 & .680 & 1 & .410 & .423 & & \\
\hline${\text { Step } 3^{\mathrm{a}}}$ & Constant & -.268 & .368 & .530 & 1 & .467 & .765 & & \\
\hline
\end{tabular}

\section{CONCLUSION}

This study found that the community has good knowledge and a supportive attitude about waste management. The community also has good behavior regarding waste management. There were no relationship between knowledge and attitudes about waste and the behavior of disposing of waste in the community of RW 06 Oro-Oro Dowo Village, Malang City. 


\section{AUTHORS' CONTRIBUTIONS}

All authors (END and A) contributed in design, data collection, data analysis, and writing the manuscript.

\section{ACKNOWLEDGMENTS}

The authors thank to all respondents that participated in this study. The authors also thank to Faculty of Sport Science, Universitas Negeri Malang that support this study.

\section{REFERENCES}

[1] Peraturan Pemerintah Republik Indonesia Nomor 81 Tahun 2012 tentang Pengelolaan Sampah Rumah Tangga dan Sampah Sejenis Sampah Rumah Tangga

[2] Undang-Undang Republik Indonesia Nomor 36 Tahun 2009 tentang Kesehatan

[3] Nurnahdiaty, Yamin S. dan Muh. Basir S. 2014. Peranan Perempuan Sebagai Provider dalam Upaya Meningkatkan Taraf Kesehatan Keluarga di Kelurahan Banta-Bantaeng Makassar. EJournal Program Pascasarjana Universitas Hasanuddin. 3 (1).

[4] Heru Subaris \& Dwi Endah. 2016. Sedekah Sampah. Yogyakarta: Prama Publishing
[5] Pemerintah Kota Malang. 2019. Pemerintah Kecamatan dan Kelurahan. (Online). https://malangkota.go.id/pemerintahan/kecamata n-dan-kelurahan/, diakses pada tanggal 14 November 2019.

[6] Fadhilah, Arief, dkk.. 2011. Kajian Pengelolaan Sampah Kampus Jurusan Arsitektur Fakultas Teknik Univesitas Diponegoro. 11 (2): 62-71.

[7] Suryani, Anih Sri. 2014. Peran Bank Sampah Dalam Efektivitas Pengelolaan Sampah (Studi Kasus Bank Sampah Malang). Jurnal Aspirasi. 5 (1): 71-84.

[8] Lestari, Raden Andriani. 2014. Pengaruh Kepemimpinan Partisipatif dan Komitmen Organisasi Terhadap Efektifitas Implementasi Rencana Stratejik pada Madrasah Aliyah di Kabupaten Sukabumi Jawa Barat. (Online), http://repository.upi.edu/11380/6/T_ADP_12021 11_Chapter3.pdf, diakses pada 18 November 2019.

[9] Kecamatan Klojen. 2019. Profil Kecamatan Klojen, (Online). https:/kecklojen.malangkota.go.id/profil/, diakses pada tanggal 14 November 2019. 